\title{
Anmeldelse:
}

\section{Med sine meningers mod}

\section{Henrik Døcker}

Hyldestskriftet til folkeretseksperten, professor emeritus Frederik Harhoff samler mange brikker til en forståelse af nutidens nye begreber og internationale institutioner, samtidig med at det kredser om en person, som ikke sjældent har talt 'Roma midt imod'.

Hanne Marie Motzfeldt, Sten Schaumburg-Müller, Rikke Gottrup og Kim Østergaard (red.): Mod og mening. Hyldestskrift til Frederik Harhoff. DJØF Forlag 2016, 617 sider.

Op mod 40 personer, omtrent alle jurister, har medvirket i næsten lige så mange kapitler til dette vældige hyldestskrift

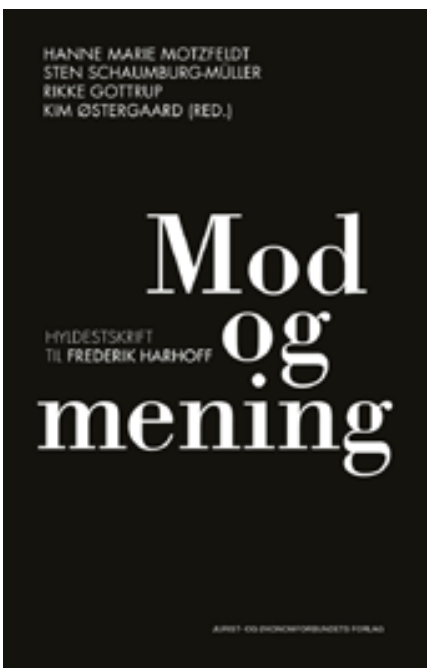
til Frederik Harhoff, indtil for nylig folkeretsprofessor ved Syddansk Universitet. Titlen Mod og mening afspejler træfsikkert, hvad der på mange måder har karakteriseret just denne mand, der ikke har været bleg for tale autoriteterne imod, og som ikke kunne undgå mediernes søgelys, da han i 2013 luftede en stærk mistanke om, at dommerne i Det Internationale Straffetribunal for Eksjugoslavien havde været under pres fra tribunalets ame-

rikanske præsident til at mildne domme over eksjugoslaviske generaler. For denne usædvanlige indsats som en slags 'whistleblower' blev Harhoff så sat fra sin daværende bestilling som dommer ved selvsamme tribunal.

Dommere skal i almindelighed vare deres mund uden for retssalen - man kan rolig sige, at deres ytringsfrihed de facto

Henrik Døcker er journalist og forfatter med international politik og ret, herunder menneskerettigheder, som speciale. Han har bl.a. udgivet Den skrøbelige fred - retsstaten og det internationale samfund [2012]. 
er begrænset; dog må Eksjugoslavien-tribunalet siges at være en alt andet end en 'almindelig' domstol. Det er opbygget med to såkaldte kamre, en førsteinstans og en appelinstans. Det var en række opsigtsvækkende frifindelser af højtstående serbiske og kroatiske militærpersoner ved andeninstansen - efter at de var dømt fængselsstraffe på over 20 år ved førsteinstansen - der gav uro.

Spektakulær var ikke mindst frifindelsen af den kroatiske hærchef Ante Gotovina, oprindelig dømt for krigsforbrydelser i det overvejende serbisk-beboede Kraijna-område i Kroatien. Harhoffs argentinske dommerkollega, Pedro Rubens David, ved tribunalet i Haag har i et interessant kapitel påpeget det skift i kravene til bevis for skyld i krigsforbrydelser, som netop appeldommen i sagen mod den serbiske general Momcilo Perisic viser.

Appelkammerets frifindelse i Perisic-sagen tilsidesatte således fuldstændig den hidtidige praksis, hvorefter en person godt kan ifalde ansvar for krigsforbrydelser, uden at vedkommende skal have udstedt en specifik ordre herom, når blot han har tilsluttet sig eller støttet en målsætning i den retning, fx etnisk rensning af bestemte områder ved med vold at fordrive en befolkningsgruppe fra det område, hvor den bor. Som den argentinske dommer anfører: "Perisic-dommen hører til en juridisk fejltagelse blandt tribunalets afgørelser”. Perisic bar ansvar for krigsforbrydelser og forbrydelser mod menneskeheden begået af proserbiske styrker 199395 i Sarajevo og Srebrenica.

Et krav om en detaljeret ordre til vold mod og drab på civile som forudsætning for ansvarspådragelse hos højerestående officerer har dog ikke dannet 'juridisk skole' i folkeretten, fremgår det af dommer Davids kapitel: Således kunne Libe- rias diktator Charles Taylor godt ved Den Internationale Særdomstol for nabolandet Sierra Leone (som i øvrigt var sat i Haag af sikkerhedsgrunde. Red.) blive dømt for sin støtte/medvirken til oprørere i Sierra Leones borgerkrig, herunder deres forfærdende krigsforbrydelser. Det er ingenlunde en forudsætning, at den kommandohavende eller politisk ansvarlige er blot $\mathrm{i}$ nærheden af de uhyrligheder, der begås. Taylor idømtes i øvrigt 50 års fængsel.

\section{Behov for ny dansk krigsforbryderlov}

Det har lang tradition i Danmark (og Vesteuropa i det hele taget) at fremstille lærde akademiske værker for at hædre fremstående personligheder, som oftest professorer, når de når til skels år og alder. For det meste kalder man disse for festskrifter. Oprindelig var genstanden for skriftet ikke nævnt direkte i bogen - bortset fra titelbladet. Ideen var, at fagspecialister hver især bidrog med et akademisk finpoleret emne, som måtte antages at interessere den, der skulle hædres. Det har ændret sig ganske meget i de senere år, i dette Harhoff-hyldestskrift så meget, at næsten hver forfatter har følt sig kaldet til et beskrive én eller anden form for personlig relation til Harhoff.

Trods disse ganske jordnære - og ind imellem underholdende - passager, er det dog ret så krævende at pløje sig igennem de lange lærde ender. Jurister skriver ud fra nogle 'relevanskriterier', som undertiden tilslører det større billede og ikke let tilfredsstiller læserens nysgerrighed efter basale facts så som 'Hvem vandt sagen'? eller 'Blev der givet erstatning og hvor meget?'. Nuvel, en skarp pointe er at finde i det kapitel, som tager til orde for, at Danmark får en ny, en ajourført, krigsforbryderlov. Det skyldes Preben Søgaard Hansen, tidligere chefrådgiver i Dansk Røde 
Kors og som sådan ansvarlig for organisationens arbejde med den humanitære folkeret, det moderne udtryk for krigens folkeret - et felt, der er skabt og udviklet af Den Internationale Røde Kors Komité, og som har været krumtap også for et nært samarbejde mellem Søgaard og Harhoff.

Danmark har - ligesom efter Anden Verdenskrig - ikke i dag en tilstrækkelig klar og specifik hjemmel til at straffe folk for krigsforbrydelser, anfører Søgaard. Og det er jo denne type forbrydelser - sammen med folkedrab og forbrydelser mod menneskeheden - der udgør just den humanitære folkeret. Danmarks officielle politik er, at straffelovens bestemmelser i tilstrækkeligt omfang kan bruges til retsforfølgning af folk, som har gjort sig skyldig i de tre former for grove folkeretsbrud. Men, som Søgaard opregner, så er det ikke forklaret, hvilke bestemmelser i straffeloven, der effektivt kriminaliserer $\mathrm{fx}$ tvangsforsvindinger (Danmark har ikke ratificeret den internationale konvention mod forsvindinger; red), tortur, en besættelsesmagts overførsel af dele af egen befolkning til et besat område og udnyttelse af civilbefolkningen til at sikre militære mål.

\section{Straffelovens torturbestemmelse}

Når FN's generalforsamling i november 2015 med samtlige 193 medlemslandes tilslutning kunne vedtage en resolution mod tortur, som Danmark havde taget initiativ til, så bør 'håndteringen' af tortur såvel i den civile som den militære straffelov være bedre, finder forfatteren, som tilføjer, at en torturbøddel i realiteten ikke kan dømmes her. En straf kan skærpes, hvis der i forbindelse med en kriminel handling er begået tortur, siger paragraffen, hvormed tortur ikke i sig selv er kriminaliseret. Det kan tilføjes, at private danske kredse forgæves med henvisning til menneskeretskrænkelser, herunder tortur, har forsøgt at få rejst sag mod diverse højtstående udlændinge - en tidligere israelsk ambassadør, en iransk udenrigsminister, en kinesisk vicestatsadvokat m.fl. under disses besøg i Danmark.

Statsadvokaturen for Særlige Internationale Straffesager gik dog så langt som til i løbet af tre dage at få afhørt personer på tre kontinenter på grund af en torturmistænkt tidligere ministers besøg, men måtte indstille efterforskningen, da der ikke kunne skaffes beviser, som kunne begrunde en anholdelse. Det har vist sig, således som vicestatsadvokat Lars Plum beskriver, at en del anmeldelser hvilede på et mildest talt skrøbeligt grundlag; misgerningerne kunne ikke bekræftes.

De manglende 'links' mellem dansk og international ret er i øvrigt blevet færre, som bl.a. en højesteretsdom fra 2012 viser: Den fastslog nemlig, at den danske lov om straf for folkedrab også omfatter folkedrab begået uden for Danmark. Der tilbagestår dog stadig et behov for at få strafhjemlet en række af de forbrydelser, der er opregnet i Rom-statutten for Den Internationale Straffedomstol, der har virket siden 2002, og som behandler sager mod ansvarlige for brud på den (ovennævnte) humanitære folkeret. I denne forbindelse kan nævnes, at Danmark endnu ingen strafbestemmelser har for forbrydelser mod menneskeheden.

Begrebet 'landsforræder' får en tur i den juridiske vridemaskine af lektor Henning Bang Fuglsang Madsen Sørensen, som henviser til et par bestemmelser i straffeloven ( $\$ 101$ og 102), der kun anvender begrebet 'krig', som - jf. omtale i Udenrigs $3 \cdot 2016$ - ikke mere benyttes i folkeretten, der i stedet taler om 'væbnet konflikt', som altså også omfatter borgerkrige. Det kan tilføjes, at det har vundet almin- 
delig hævd, at Den Internationale Røde Kors Komité afgør, hvornår væbnede optøjer har udviklet sig til en borgerkrig, en intern væbnet konflikt, således at krigens folkeret og dertil hørende Geneve-konventioner kan anvendes. Så sent som i december 2015 suppleredes straffeloven med en ny bestemmelse, som hjemlede straf på indtil ti års fængsel for den, som under en væbnet konflikt kæmper mod den danske stat. Så var der også taget højde for danske pro-IS-kæmpere

\section{Alle oprørere terrorister?}

Strafferetsprofessor Jørn Vestergaard udtrykker betænkelighed ved de nyligt indførte ændringer i den danske paslov, der muliggør, at politiet kan nægte pasudstedelse til mistænkte eller potentielle 'fremmedkrigere' (aktuelt Syrien/ Irak-krigere) - og det på en sådan måde, at kravene til bevis for mistanke er betydelig lempeligere end til denne lovs andre bestemmelser.

Hans reference til pasinddragelsen hos den dansk-kurdiske kvinde Joanna Palani, der flere gange er draget af sted for at kæmpe mod IS sammen med irakiske YPG-styrker, er efter min mening for kortfattet. Begrundelsen for pasinddragelsen var, at YPG i et vist omfang samarbejder med den tyrkisk-kurdiske formation PKK, som er opført på EU's liste over terrororganisationer. Vestergaard vender sig mod, at organisationer som EU og Europarådet i nogle resolutioner refererer til udenlandske terroristiske krigere på en så bred måde, at alle medlemmer af visse oprørsbevægelser stemples som terrorister.

Hertil kommer, at nogle regime benytter anti-terrorlovgivningen til at bekæmpe lokale oprørsbevægelser, idet konflikten angiveligt står mellem et legitimt styre og lovløse forbrydere og terrorister, der så ikke kan forvente rettigheder efter den humanitære folkeret.

I denne store 'hob' findes både kurdere, tibetanere, kinesiske uighurer, tjetjenere, palæstinensere og enheder af den frie syriske hær. Kort sagt: Handlinger, som ikke i sig selv er ulovlige i forbindelse med en væbnet konflikt. skal ikke inddrages under en national terrorlovgivning. Helt grundlæggende bevæger Danmark sig på kanten af menneskerettighederne, når det generelt kræver forhåndstilladelse til en udlandsrejse, konkluderer Vestergaard. Ja, også andetsteds er retten til at begrænse egne borgeres udrejse stærkt begrænset, nemlig i FN's konvention om de borgerlige og politiske rettigheder.

Det store værk byder på et væld af emner så som behovet for bedre beskyttelse af whistleblowers; Irak-kommissionens kranke skæbne; mindretalsstyre i Danmark og de øvrige nordiske lande; persondatabeskyttelse; Guantanamo-fangernes retsløshed; den beskedne betydning af FN's kontrolkomiteer; et muligt behov for at udvide folkerettens område osv. osv. Det er svært at finde væsentlige kritikpunkter i en sådan samling lærde fremstillinger. Det skulle da lige være redaktørernes manglende vilje eller evne til at få de mange forfattere til at præsentere sig på ensartet måde. At ganske få bidrag er på engelsk vil næppe genere mange, men man spørger sig selv om årsagen? Få udlændinge vil vel kaste sig over en bog med så lidt på engelsk. Det må imidlertid hilses med glæde, at hver forfatter resumerer indholdet af sit bidrag på en nogenlunde overskuelig måde. 